Program for Promoting Social Science Research

Aimed at Solutions of Near-Future Problems

Design of Interfirm Network to Achieve Sustainable Economic Growth

Working Paper Series No.25

\title{
Natural Disaster and Natural Selection
}

\author{
Hirofumi Uchida \\ Daisuke Miyakawa \\ Kaoru Hosono \\ Arito Ono \\ Taisuke Uchino \\ and \\ lichiro Uesugi
}

March 28, 2013

Research Center for Interfirm Network

Institute of Economic Research, Hitotsubashi University

Naka 2-1, Kunitachi-city, Tokyo 186-8603, JAPAN

Tel: +81-42-580-9145

E-mail: hit-tdb-sec@ier.hit-u.ac.jp

http://www.ier.hit-u.ac.jp/ifn/ 


\title{
Natural Disaster and Natural Selection ${ }^{\dagger}$
}

\author{
Hirofumi Uchida (Kobe University) ${ }^{\ddagger}$ \\ Daisuke Miyakawa (Development Bank of J apan-RICF) \\ Kaoru Hosono (Gakushuin University / Ministry of Finance) \\ Arito Ono (Mizuho Research Institute) \\ Taisuke Uchino (Daito Bunka University / RIETI) \\ Iichiro Uesugi (Hitotsubashi University / RIETI)
}

March 2013

† This study is an achievement of the Study group for Earthquake and Enterprise Dynamics (SEEDs), which participates in the project "Design of Interfirm Networks to Achieve Sustainable Economic Growth" under the program for Promoting Social Science Research Aimed at Solutions of Near-Future Problems, conducted by the Japan Society for the Promotion of Science (J SPS), the Research on Efficient Corporate Financing and Inter-firm Networks at the Research Institute of Economy, Trade and Industry (RIETI), and the Academic Investigation Project into the Great East J apan Earthquake by the J SPS. The authors would like to thank Makoto Hazama for his superb research assistance, Miho Takizawa for her helpful comments, Hitotsubashi University for financial support and to Teikoku Databank, Ltd. for data provision. K. Hosono gratefully acknowledges financial support from Grant-in-Aid for Scientific Research (S) No. 22223004, J SPS, and H. Uchida acknowledges support from Grant-in-Aid for Scientific Research (B) No. 22330096, J SPS.

₹ Graduate School of Business Administration, Kobe University, 2-1 Rokkodai, Nada, Kobe 657-8510, J apan. Tel.\&Fax.: 81-78-803-6949, E-mail: uchida@ b.kobe-u.ac.jp. 


\title{
Natural Disaster and Natural Selection
}

\begin{abstract}
In this paper, we investigate whether a natural selection mechanism works for firm exit. By using data of firms after a devastating earthquake, the Great Tohoku Earthquake, we examine the impact of firm efficiency on firm exit both inside and outside the earthquake-affected areas. We find evidence suggesting that more efficeint firms are less likely to exit both inside and outside the affected areas, which supports the natural selection mechanism. However, we also find that the mechanism is weaker for those firms whose main banks were damaged by the earthquake, which suggests that damage to banks weakens the natural selection mechanism. We also apply the same methodology to the case of the Great Hanshin-Awaji Earthquake, and again find that the natural selection mechanism works both inside and outside the affected areas. However, no significant impact of bank damage is found on the exit probability of a firm.
\end{abstract}

Keywords: firm exit, natural selection, earthquake, natural disaster, evergreening

J EL classification codes: L10, G21 


\section{Introduction}

Natural disasters inflict serious damages to firms. They destroy firms' tangible assets such as buildings and equipment as well as human capital, and thereby deteriorate production capacity of the firms. Such adverse impacts might sometimes be fatal and force the firms to close down their businesses.

An intriguing question concerning firm exit caused by natural disasters is how the selection mechanism works, i.e., what are the characteristics of the firms that natural disasters force to exit. As for the impact of natural disasters on economic growth, empirical studies find mixed evidence, and some studies even report a positive impact. ${ }^{1}$ As an account for the positive impact, existing evidence finds that natural disasters might enhance productivity of the economy's corporate sector (Skidmore and Toya 2002, Crespo-Cuaresma et al. 2008). Such evidence suggests that a natural selection mechanism might work where natural disasters force inefficient firms to exit. However, because existing evidence is based on aggregate data, detailed mechanisms behind the disaster impact is unclear, and no studies have examined the selection mechanism of natural disasters.

A closely related question that is inseparably intertwined with the one above is how the selection mechanism inflicted by natural disasters differ from that in other, i.e., non-disaster, environment. A selection mechanism is working irrespective of disaster happening. Since the early pioneering works such as Schumpeter (1939), Alchian (1950), J ovanovic (1982), there is long-standing literature that explores the mechanism through which the market eliminates inefficient firms, especially during the recession

${ }^{1}$ For a survey see, for example, Noy and Vu (2010) and Loayza et al. (2012), and references therein. 
period (e.g., Bertin, et al. 1996, Bresnahan and Raff 1991, Caballero and Hammour 1994, 1996, 2005). Similar studies have conducted in J apan to examine whether unnatural selection mechanism worked, or whether there were many zombie firms, as a cause of the so-called "lost decades" from 1990s (see, e.g., Kim 2004, Ahearne and Shinada 2005, Nishimura et al. 2005, Fukao and Kwon 2006, Caballero et al. 2008). ${ }^{2}$ However, to the best of our knowledge, no studies have compared the selection mechanisms in an ordinary and a disaster environments.

The aim of this paper is to clarify the mechanism of firm exit during the aftermath of the devastating Great Tohoku Earthquake (also known as the Great East-J apan Earthquake) that hit the Tohoku area of J apan on March 11, 2011. ${ }^{3}$ We use data of many small- and medium-sized enterprises (SMEs) in the Tohoku area, which include information on firms' attributes, financial statements, their main banks, and the information on firms' exit during the aftermath of the earthquake. We also identify those firms that directly damaged by the earthquake and those that did not as, respectively, firms whose headquarters are inside and outside the earthquake-affected areas.

We estimate a probit model of firm exit by using variables to indicate different characterics of firms and of their lending banks as independent variables. To examine whether or not a natural selection mechanism works, we use a proxy for firm efficiency

\footnotetext{
2 Note that Sakai et al. (2010) find evidence inconsistent with the simplistic story that evergreening loans contributed to keep zombies alive as far as small- and medium-sized enterprises are concerned. Also, (large) zombie firms recovered afterwards through restructuring (Fukuda and Nakamura 2011).

3 This earthquake together with accompanying tsunami and the accident of the nuclear plant in Fukushima brought about 27,154 casualties (18,131 dead, 2,829 missing, and 6,194 injured) (Fire and Disaster Management Agency of the Government of J apan: http:// www.fdma.go.jp/ $\mathrm{bn} /$ higaihou/pdf/jishin/ 146.pdf (in J apanese)) and as of this writing, many people around the vast areas adjacent to the nuclear plant are still suffering from the evacuation.
} 
as our main independent variable. To examine the relevance of the selection mechanism inside and outside the earthquake-affected areas, we use an interaction term between the proxy for firm efficiency and an indicator of the firms' location inside the affected areas. This allows us to explore the differences between the selection mechanism inflicted by natural disasters and the one in an ordinary (but post-earthquake) environment.

In addition to investigating whether natural selection mechanisms work inside and outside the affected areas, we also ask two empirical questions. First, we naturally ask whether direct damages to firms inflicted by the earthquake increases the likelihood of them being forced out. There are a few studies that focus on the impact of natural disasters on firm recovery (Leiter et al. 2009, De Mel et al. 2011, Hosono, et al. 2012), but to the best of our knowledge, there is no studies that explicitly examine the impact of natural disasters on firm exit. A natural conjecture is that the exit is more likely to be observed inside the affected area, but this may not be the case to the extent that more damaged firms obtain greater financial aids or public support.

We also ask whether the damage to firms' lending banks has any impact on firm exit. Regarding zombie firms in J apan after the bubble period, many existing studies resort the malfunctioning of the selection mechanism to evergreening loans by banks (see e.g., Sekine et al. 2003, Peek and Rosengren 2005, Fukuda, et al. 2006, Caballero et al. 2008). Similar to these studies, we examine whether deteriorating bank health due to earthquake damage might have contributed to unnatural selection, if any. In this ven, we create proxies for the damages that firms' lending banks suffer from. Interacting these variables with the proxy for firm efficiency allows us to examine whether damaged banks contributed to promote a natural or unnatural selection 
mechanism. We also examine the direct impact of bank damage on the exit probability.

The most significant contribution of our analysis is being able to compare the selection mechanisms inside and outside the affected areas by using a detailed micro data set. To respond to the questions raised above, we investigate the difference in the impact of firm efficiency on firm exit for the combination of inside/outside firms transacting with inside/ outside banks. For those firms located outside the affected areas, bank damage is a pure exogenous financial shock. This allows us to circumbent the troublesome endogeneity between bank and firm performances.

From the regression analysis, we find that the probability for firm exit is lower for more efficient firms both inside and outside the affected areas. This supports the hypothesis that a natural selection mechanism works. However, we also find that the statistical association between firm efficiency and their exit probability is weaker if the firms' main banks were damaged. We also find that the level of the exit probability of a firm is lower when its main bank is damaged. These findings mean that although a natural selection mechansim work irrespective of disaster happening, damage to the main bank reduces the exit probability of its borrowing firm, either directly or indirectly through mitigating the natural selection.

Although our findings on the effect of bank damage are counter-intuitive, they are consistent with an interpretation that governments' support to damaged banks through different measures such as rescue funding or capital injection contributed to an increase in their lending capacity, resulting in more funding to less efficient firms. Our findings are also consisntent with an alternative interpretation that damaged banks extended evergreening loans to less efficient firms. 
As an additional exercise, we also apply our methodology to a different and also devastating earthquake in Japan: the Great Hanshin Earthquake that hit the area around Kobe city and Awaji Island on J anuary 17, 1995. From the same data source, we can also construct a similar sample of firms inside and outside the areas affected by the Great Hanshin Earthquake.

By running a similar probit regression, we again find that the natural selection mechanism works both inside and outside the affected areas. However, we do not find the significant impact of bank damage on the exit probability of a firm. At the time of the Great Hanshin Earthquake, the Government did not provide as much supports to damaged banks as it did at the time of the Great Tohoku Earthquake. Hence, to the extent that the banks' motivations to (or not to ) extend evergreening loans are the same between the periods of the two earthquakes, our contrasting findings between the two earthquakes lends more support to the interpretation that financial aids to damaged banks contributed to enhance their lending capacity, which as a result allowed inefficient firms to survive.

The remaining part of this paper is composed of as follows. The next section explains data and methodology. Section 3 reports the results. Section 4 is for the analysis of the Great Hanshin-Awaji Earthquake. The final section concludes the paper.

\section{Data and methodology}

\subsection{Data}

The main source of our data is firm-level credit files compiled by Teikoku Databank ltd. (TDB), a leading business credit bureau in J apan. Information on firms' 
attributes, financial statements, their lending banks, and exits is available from the credit files. We first pick those firms whose headquarters are located in the six earthquake-affected prefectures (Aomori, Iwate, Miyagi, Akita, Yamagata, and Fukushima) as of the time the Great Tohoku Earthquake hit the area, as a starting sample. The areas seriously damaged by the earthquake are located inside these prefectures, and so damaged as well as non-damaged firms are included in our sample. We exclude those firms that are located in other prefectures to eliminate differences in unobserved characteristics stemming from region-specific factors. Within the six prefectures, we have information of firm exit after March 11, 2011 when the Great Tohoku Earthquake hit for 87,470 firms, and among them 443 are recorded as exit firms after the earthquake (on March 2011 and after).

We then eliminate those firms for which variables to indicate firm characteristics or information to identify their main banks are not available. To identify main banks, we use a list of the banks with which the firms transact with that is included in the TDB database. In this list, banks are listed in the order of importance to the firms. Following widely used convention, we define the bank listed at the top as the firms' main banks.

We also augment our data set with data of these main banks. We add variables from the banks' financial statements that are obtained from the Nikkei NEEDS Financial Quest compiled by Nikkei, Inc. (Nihon Keizai Shimbunsha) and Financial Statements of Shinkin Banks and Credit Cooperatives from the Kin-yu Tosho Consultant Corporation. We further augment our data set with information about the main banks' branches. We add information of the location (address) of the banks' branches obtaind from Nihon Kin-yu Meikan of Nikkin Publishing. Because the 
financial statements are not available for certain types of banks, we eliminate those firms whose main banks are neither a city bank, a regional bank, a Shinkin bank, nor a credit cooperative.

\subsection{Regression and variables}

\subsubsection{Regression}

We run a probit regression of firm exit in the following form.

$$
\operatorname{Pr}\left[\text { Exit }_{\mathrm{i}}=1\right]=\operatorname{Pr}\left[\mathrm{y}_{\mathrm{i}}{ }^{*}>0\right],
$$

where

$$
\mathrm{y}_{\mathrm{i}}{ }^{*}=\mathbf{X}_{\mathrm{i}} \mathrm{b}+\mathrm{e}_{\mathrm{i}}
$$

and $\mathrm{i}=1, \ldots, \mathrm{N}$ is an indicator for each of the $\mathrm{N}$ sample firms.

The variable Exit is an indicator of firm exit. The variable $\mathrm{y}_{\mathrm{i}}{ }^{*}$ is the latent variable to determine the probability of exit, and the vector $\mathrm{X}_{\mathrm{i}}$ indicates the independent variables. The final term $\mathrm{e}_{\mathrm{i}}$ is an ordinary error term. The definition and the descriptive statistics of these variables are shown in Table 1, where the statistics are also compared depending on whether the firms are damaged or not by the earthquake. The details of the variables are to be explained below.

To circumbent any endogeneity, we use the pre-earthquake value of the independent variables, except for variables to indicate earthquake damages. More precisely, we use their value as of the most recent available dates during the past one year of the earthquake. ${ }^{4}$

4 More precisely, we take financial statement data at the end of the fiscal year 2010, which is March 31, 2011. Although March 31 is after the earthquake (March 11), most of the economic activities reflected in financial statements of fiscal 2010 is before the earthquake. As for other 


\subsubsection{Main variables}

Our dependent variable is the indicator of firm exit, Exit. This is a dummy variable taking the value of one if the firm is recorded as an exit firm from March 2011 to November 2012. Those firms that voluntarily closed down their businesses are not included in exit firms.

The main empirical question of this paper is whether there is a natural or unnatural selection mechanism working, or whether inefficient firms have higher likelihood of exiting, inside and outside the affected areas. Many existing studies on the selection mechanism use firms' total factor productivity (TFP) as a measure of firm efficiency. However, even a crude measure of TFP requires financial statement data of the firms. In our data set, the number of observation for which such data is available is very small if we focus on firms that are located inside the affected area and to which damaged banks lend. Because such firms are one of the main categories of firms that we focus on in this paper, we decided not to use TFP measures.

Instead, we decided to use firms' score, F_SCORE, that TDB calculates as our measure of firm efficiency. The score takes an integer value on a 1- 100 scale, and evaluates the soundness of the firm's management, the firm's repayment ability, and whether the firm is a safe trade counterpart, from a third-party viewpoint. The score is calculated based on a quantitative evaluation of financial figures, past performances, the operating history of the firms, and the qualitative evaluation of firms by the TDB's researchers (including the evaluation of their managers (CEOs)). This score is of TDB's search, multiple data might be available. In such a case, we used the most recent ones. 
calculated on an unsolicited basis, i.e., the firms do not pay for being rated.

Another important variable is an indicator for firm damage. To create this variable, we identify whether firms' headquarters are located in the earthquake-affected areas inside the six prefectures based on the most recent data available before the earthquake. The affected areas are defined as cities and towns in the six prefectures that were included in the Japanese Government's Act Concerning Special Financial Support to Deal with a Designated Disaster of Extreme Severity. Our firm damage variable F_DAMAGED takes a value of one if the firms' headquarters are located inside the affected area. ${ }^{5}$

Also important to our analysis is a variable to indicate bank damage, B DAMAGED. We use two alternative variables as proxies for bank damage. As explained above, we define main banks of our sample firms as those listed at the top of the banks they transact with. Our first bank damage variable, B_HQDAMAGED, is an indicator variable that takes a value of one if the banks' headquarters are located inside the affected area. Our second bank damage variable is created based on information of the location of the banks' branch offices. The variable B_BRDAMAGED is the ratio of the number of branches inside the affected areas to the total number of the branch offices that the main banks have.

Using these variables we not only examine the selection mechanisms inside and outside the affected areas, but also the difference in the mechanisms depending on the level of the damage that the firms' main banks suffer from the earthquake. Thus, our main independent variables are threefold: (1) F_SCORE in its isolation, (2) an

5 This definition does not capture firm damage to their establishments other than headquarters, but because many firms in our sample are small- and medium-sized enterprises, multi-establishment firms are minority. 
interaction term of F_SCORE and F_DAMAGED, and (3) an interaction term of F_SCORE and B_DAMAGED. These variables respectively allow us to examine (1) whether the selection mechanism is natural or unnatural, and whether the selection mechanisms differ depending on the presence/ absence of (2) firm damage and (3) bank damage. We also use F_DAMAGED and B_DAMAGED as independent explanatory variables, which enables us to clarify the direct impact of these damages on the exit probability of the firms.

The upper half of Table 1 shows descriptive statistics of our main variables. The first column reports the statistics for the whole sample (column (1)). Columns (2) and (3) respectively shows the statistics for firms with F_DAMAGED $=1$ (31,447 firms), and for those with $F_{-}$DAMAGED $=0(56,023$ firms). The fourth column reports the results for the test of the difference in means for those firms with $F_{-}$DAMAGED $=1$ and $=0$ for each variable.

First, the first line shows (for Exit) that of the 87,470 firms, only 0.5\% (443 firms) are recorded as exited. That the ratio of exit firms are lower for damaged firms than for non-damaged firms is somewhat counter-intuitive, but the difference is small. Second, the mean firm score (F_SCORE) is 43.5. The score for damaged versus non-damaged firms are comparable, but the test statistic shows that the mean score for damaged firm is significantly smaller than that for non-damaged ones. Third, for $40 \%$ of the firms, their main banks are suffered from the earthquake at their headquarters. The ratio is higher for damaged firms, implying that firms are transacting with nearby banks. Similar results are also found as a higher ratio of B_BRDAMAGED for damaged firms than for non-damaged ones. 


\subsubsection{Control variables}

We also use many control variables to isolate the impact of the above four variables on firm exit. The variables to represent firm characteristics are: F_EMP, the number of employees (firm size); F_AGE, the age of the firm; and F_NBANK, the number of banks that the firm transacts with. We also use industry dummies. The lower half of Table 1 shows that the sample firms on average have 14 employees, are 30 years old, and transact with 2 banks.

Variables to represent characteristics of the main banks are also used: B_ROA, ROA of the main bank defined as ordinary profit over total asset; B_CAP, capital asset ratio of the main bank; and B_lnASSET, the natural logarithm of the main bank's total asset (bank size). For these variables, Table 2 shows their descriptive statistics at the bank level (rather than the firm level). Our sample firms transact with 120 banks. Their average ROA is $0.2 \%$, and the capital asset ratio (book value) is $4.8 \%$. Table 2 also shows the statistics depending on whether the banks suffered from earthquake (based on B_HQDAMAGED). The test statistics show that ROA and the capital asset ratio are comparable across damaged and non-damaged banks, although damaged banks are slightly smaller in asset size.

\section{Results}

\subsection{Main results}

Table 3 shows our regression results. Column (1) of this table reports the results when we use B_HQDAMAGED (headquarter damage) as a bank damage variable, and column (2) reports the results when we use B_BRDAMAGED (branch damage). The coefficients are the marginal effects of respective variables, and the 
heteroskedasticity-robust standards errors are shown in the parentheses. Looking first at control variables, the probability of firm exit is higher for smaller firms ( $F_{-}$EMP), firms transacting with more banks ( $F_{-}$NBANK), and firms transacting with weakly capitalized banks (B_CAP). The final finding is consistent with previous studies on capital crunch, where less capitalized banks shrink lending to meet the regulatory capital requirement (e.g., Peek and Rosengren 1995).

As for the variables of our interest, the firms' score (F_SCORE) has a negative and statistically significant coefficient in both columns. This means that non-affected firms that transact with non-affected banks are less likely to exit as their scores become higher. This finding is consistent with a natural selection mechanism. The magnitude of the coefficient means that for an average firm, one-point increase in F_SCORE reduces the probability of exit by 0.0137 (column (1)) or 0.0158 (column (2)) percentage points.

Turning to the interaction terms, the coefficient for the interaction term of F_SCORE and F_DAMAGED is insignificant. This means that firm damage neither promotes nor demotes the natural selection mechanism. However, the interaction term of F_SCORE and B_DAMAGED has a statistically significant coefficient in both columns. Irrespective of whether bank damage is measured by headquarter damage or branch damage, it increases the probability of exit of the higher-score borrowers. The magnitude of the coefficient in column (1) means that for an average firm, the increase in the probability of exit due to one-point increase in F_SCORE is higher by 0.0077 percentage points when they transact with a damaged main bank than when they transact with a non-damaged one. However, the coefficient does not offset the negative coefficient for $F_{-}$SCORE. This means that even for firms with B_DAMAGED 
$=1$, the selection mechanism is natural.

To evaluate the overall effect of F_SCORE for different categories of firms, we also need to focus on the results on F_DAMAGED and B_DAMAGED in their isolation. In column (1), the coefficient for F_DAMAGED is insignificant, but it is positive and weakly significant in column (2). This implies that direct damage to firms may increase the probability of the exit of the firm. Although this finding is weaker than intuitively expected, financial aids and public support might have contributed to reduce the probability of exit of damaged firms.

The coefficient for B_DAMAGED is negative and statistically significant in both columns. This suggests that bank damage has a positive effect on the survival of the firm, which appears to be counter-intuitive. The magnitude of the coefficient means that the probability of firm exit is lower by 0.400 percentage point (column (1)) if the firm transacts with a damaged bank (as compared those with a non-damaged bank), or by 0.897 percentage point (column (2)) for one-point increase in the main banks' ratio of damaged branches. We will discuss possible interpretations of these results in the next subsection.

\subsection{Discussion and Interpretations}

To comprehend the economic significance of the results in Table 3, this subsection provides an illustrative representation of the overall effects of firm efficiency on the exit probability. Because the interpretation is more intuitive, we focus on the results in column (1) of Table 3, where the bank damage variable used is a dummy variable B_HQDAMAGED. Column (1) of Table 3 shows that in this specification, F_DAMAGED and its interaction with F_SCORE are statistically insignificant. We 
thus focus on the difference in the impact of firm efficiency between those firms whose main banks are damaged and those whose main banks are not damaged.

In Figure 1, we depict the predicted exit probabilities in this case. The height of the lines (Y-axis) indicates the predicted probabilities, which are measured for different values of F_SCORE (X-axis) around its mean for the range of two sigmas (i.e., two standard deviations). ${ }^{6}$ The solid line is for those firms with B_HQDAMAGED $=0$ (without bank damage), and the dotted line is for those with B_HQDAMAGED $=1$ (with bank damage). To calculate the predicted probabilities, we first calculate the predicted values of the latent variable $\mathrm{y}_{\mathrm{i}}^{*}$, and then obtain corresponding probabilities that follows the standard normal distribution. ${ }^{7}$

The two lines depicted in this figure confirm the findings above. First, both lines are downward-sloping, meaning that the exit probability declines as the firm's score improves. This finding is consistent with the natural selection mechanism where efficient firms are less likely to exit. Also, the solid line is steeper than the dotted line, meaning that bank damage weakens the workings of the natural selection mechanism.

What is newly found in this figure is the difference in the absolute level of the exit probability for firms with B_HQDAMAGED $=0$ and firms with B_HQDAMAGED $=1$. This figure shows that, at least as far as firms depicted here (i.e., for those firms whose scores fall into the range of the two sigmas around the mean), the dotted line is located below the solid line. This means that the exit probability is consistently lower for

6 The mean of F SCORE is 43.5 and its standard deviation is 10 (see Table 1 ).

7 To calculate the predicted value of the latent variable $y_{i}^{*}$, we first sum the product of the mean of each independent variable and its estimated coefficients for those variables other than F_SCORE (or F_SCORE $\times$ B_DAMAGED) and B_DAMAGED. We then add the product of the value of $\mathrm{F}$ SCORE (shown on the X-axis) and its estimated coefficient (which are different when B DAMAGED $=0$ and $=1$ ). In the case of B DAMAGED $=1$ (dotted line), we further add the estimated coefficient for B_DAMAGED. 
firms with B_HQDAMAGED $=1$ than for those with B_HQDAMAGED $=0$ for many values of F_SCORE. Thus, the direct effect of main bank damage to decrease the exit probability is strong for many firms.

On balance, we find that damage to the main bank contributes to reduce the exit probability of the borrowing firms, either through its direct impact or by mitigating the natural selection mechanism. The findings are significant because for those firms located outside the affected areas, damage to their main banks is a pure financial shock to them. Thus, these findings are not subject to endogeneity between firm and bank performances.

However, these findings are counter-intuitive. There are two possible interpretations for these findings. First, damaged banks obtained many financial aids, including rescue funding from the Bank of Japan and capital injection using public funds. ${ }^{8}$ These might have contributed to provide more funds to less efficient firms, thereby allowed them to survive. Second, these findings might suggest that damaged banks are extending evergreening loans, especially to less efficient firms. Existing studies found evergreening loans by weakly capitalized banks in Japan during the banking crisis in the 1990s (see e.g., Sekine et al. 2003, Peek and Rosengren 2005, Fukuda, et al. 2006, Caballero et al. 2008). Although we control for such evergreening by B_CAP, evergreening due to deteriorated bank health or lending capacity caused by the earthquake damages might be the cause for the finding above. However, these are mere speculation and more investigation is needed to identify the

8 From May 2011, the Bank of J apan started to supply funds to financial institutions in disaster areas as the special funds-supplying operation, which aims to support such financial institutions to meet demand for funds for restoration and rebuilding. Also, the Government of Japan injected capital to regional financial institutions in the disaster areas from September 2011 to March 2012. 
true cause.

\section{Great Hanshin-Awaji Earthquake}

In this section, we apply the same methodology to the case of the Great Hanshin-Awaji Earthquake that hit the areas around Kobe city and Awaji Island of J apan on J anuary 17, 1995, 16 years before the Great Tohoku Earthquake. ${ }^{9}$ Before the Great Tohoku Earthquake, the Great Hanshin-Awaji Earthquake had been considered as an "unprecedented" disaster that would happen only once in hundred years.

There are many differences in the two earthquakes. Compared with the Great Tohoku Earthquake, the affected areas of the Great Hanshin-Awaji Earthquake are far concentrated, mostly in urban areas. The latter did not accompany tsunamis, but instead inflicted many casualty by fires it broke out. However, both earthquakes brought about massive damage. Thus, by comparing the findings between two earthquakes, we might be able to draw more information on how the selection mechanism work and the impact of bank damage on firm exit.

\subsection{Data and Methodology}

The regression to run is the same as that explained in section 2.2.1, and the sources of the data are the same as well. Sample firms in this analysis are 13,509 firms that are headquartered in Hyogo and Osaka prefectures. Firms and banks that are considered as damaged if their headquarters (or bank branches) are located inside the affected areas, which are defined as the towns and the cities in the two prefectures that

9 The number of casualty is 50,227 (6,432 dead, 3 missing, and 43,792 injured) (the Cabinet Office of the Government of J apan: http:// www.bousai.go.jp/4fukkyu_fukkou/hanshin_awaji/ 101.pdf). 
were included in the J apanese Government's Act Concerning Special Financial Support to Deal with a Designated Disaster of Extreme Severity.

Table 4 shows the descriptive statistics of the variables used in this analysis. Most of the variables are the same as those for the Great Tohoku Earthquake, but some are not available. Most importantly, F_SCORE is not available, which makes it impossible to exactly compare the results across the two earthquakes. As a replacement of F_SCORE, we decided to use ROA of the firm, F_ROA, defined as the ratio of ordinary profit to total asset as a proxy for firm efficiency. We can make use of two additional variables, $\mathrm{F}_{-} \mathrm{CASH}$, the ratio of cash or deposits to total assets, and F_LEV, the firm' leverage, as control variables. Similar to the analysis on the Great Tohoku Earthquake, to circumvent any endogeneity we use the most recent values of the independent variables that are available during the past one year of the earthquake except for variables to indicate earthquake damage.

The variable Exit in this case is defined as those recorded as exit firms during three years after January 1995. Compared with Table 1, the ratio of exit firms (1.5\%) is higher, even if we take into account the difference in the window period (three years for the Great Hanshin-Awaji Earthquake and one year for the Great Tohoku Earthquake). Also compared with Table 1, the firms are larger (in employee size) and older, and transact with a larger number of banks, presumably due to the fact that the earthquake took place in the urban area.

\subsection{Results}

Table 5 reports the regression results for the case when B_DAMAGED = B_HQDAMAGED (column (1)) and = B_BRDAMAGED (column (2)). We find that 
most control variables indicating firm characteristics are strongly significant. Larger, older, and cash-rich firms are less likely to exit, and firms transacting with a larger number of banks are more likely to exit. In consistent with Table 3, we do not find that less capitalized main banks (measured by B_CAP) increase the exit probability.

The results for the main variable, F_ROA, is consistent with Table 1. Firms with a higher ROA are less likely to exit. The natural selection mechanism is again supported for non-damaged firms transacting with non-damaged banks. However, the other important variables are statistically insiginificant, except for B BRDAMAGED in its isolation. In the case of the Great Hanshin-Awaji Earthquake, we do not find any impact of earthquake damage on exit probability, either directly or indirectly thorough the effect of firm efficiency.

Compared with Tables 3, the most significant difference in the results in Table 5 is the lack of (or weaker) significance of $F_{-}$ROA $\times$B_DAMAGED and B_DAMAGED. As discussed in section 3, there are two possible interpretations for the overall impact of bank damage to increase the exit probability: an increase in lending by damaged banks due to rescue funding or capital injection to such banks, or evergreening by damaged banks. Compared with the Great Tohoku Earthquake, institutional measures to publicly rescue damaged firms and damaged banks were not well-established and the actual rescue measures were less extensive in the case of the Great Hanshin-Awaji Earthquake. Taking into account this difference, if the underlying mechanisms were the same between the two great earthquakes, the lack of the impact of B_DAMAGED for the Great Hanshin-Awaji Earthquake and the presence of such an impact for the Great Tohoku Earthquake supports the interpretation relying on financial aids to damaged banks. However, we also need to take into account many differences 
between the two periods of the earthquakes, including differences in bank regulation and supervision.

\section{Conclusion}

In this paper, we investigated the selection mechanism of firms using sample of the firms located inside and outside the affected areas of the Greeat Tohoku Earthquake. We found that for firms with higher firm score, a proxy for firm efficiency, the probability of firm exit is smaller, which supports the natural selection mechanism. However, we also found that the mechanism is weaker and the exit probability itself is smaller for those firms whose main banks were damaged. These findings suggest that bank damage contributes to reduce the exit probability of its borrowers. Although these findings are counter-intuitive, they are consistent with an interpretation that damaged banks increased lending capacity due to rescue funding or capital injection, resulting in less efficient firms to survive. Alternatively interpretation might be that damaged banks extended evergreening loans.

We also applied a similar methodology to firms inside and outside the affected areas of the Great Hanshin-Awaji Earthuake. Again we found that the natural selection mechanism works. However, we did not find the significant impact of bank damage on the exit probability. Because damaged banks at the time of the Great Hanshin-Awaji Earthuake did not receive significant financial support from the government, the latter finding is consistent with the interpretation that financial aid to damaged banks was important. However, more future work is needed to ascertain the exact cause of these findings. 


\section{References}

Ahearne, A., and N. Shinada, (2005), Zombie firms and economic stagnation in Japan, International Economics and Economic Policy 2, 363-381.

Alchian, A.A. (1950). "Uncertainty, Evolution, and Economic Theory." Journal of Political Economy 58(3): 211-221.

Bertin, A.L., T.F. Bresnahan, and D.M.G. Raff (1996). "Localized Competition and the Aggregation of Plant-Level Increasing Returns: Blast Furnaces, 1929-1935." Journal of Political Economy 104(2): 241-266.

Bresnahan, T.F. and D.M.G. Raff (1991). "Intra-Industry Heterogeneity and the Great Depression: The American Motor Vehicles Industry, 1929-1935." Journal of Economic History 51(2): 317-331.

Caballero, R.J. and M.L. Hammour (1994). "The Cleansing Effect of Recessions." American Economic Review 84(5): 1350-1368.

Caballero, R.J. and M.L. Hammour (1996). "On the Timing and Efficiency of Creative Destruction." Quarterly Journal of Economics 111(3): 805-852.

Caballero, R.J. and M.L. Hammour (2005). "The Cost of Recessions Revisited: A Reverse-Liquidationist View." Review of Economic Studies 72(2): 313-341.

Caballero, R.J., T. Hoshi, and A.K. Kashyap, (2008), Zombie lending and depressed restructuring in Japan, American Economic Review 98, 1943-77.

Crespo Cuaresma, J., J. Hlouskova, and M. Obersteiner, (2008), Natural disasters as creative destruction? Evidence from developing countries, Economic Inquiry 46, 214-226.

De Mel, S., D. McKenzie and C. Woodruff. (2011), Enterprise Recovery Following Natural Disasters. Economic Journal 122, 1-28.

Fukao, K., and H.U. Kwon, (2006), Why did Japan's TFPgrowth slow down in the lost decade? An empirical analysis based on firm-level data of manufacturing firms, Japanese Economic Review 57, 195-228.

Fukuda, S., M. Kasuya, and J. Nakajima, (2006), Deteriorating bank health and lending in Japan: Evidence from unlisted companies under financial distress, Journal of the Asia Pacific Economy 11, 482-501.

Fukuda, Shin-ichi, and Jun-ichi Nakamura, (2011), Why did 'zombie' firms recover in Japan? World Economy 34, 1124-1137.

Hosono, K., D. Miyakawa, T. Uchino, M. Hazama, A. Ono, H. Uchida, and I. Uesugi (2012). Natural disasters, damage to banks, and firm investment. RIETI Discussion Paper 12-E-062.

Kim, S., (2004), Macro effects of corporate restructuring in Japan, IMF Staff Papers 51, 
457-492.

Leiter, A.M., H. Oberhofer, and P.A. Raschky. (2009). "Creative Disasters? Flooding Effects on Capital, Labor and Productivity within European Firms.” Environmental and Resource Economics 43, 333-350.

Loayza, N.V., E. Olaberría, J. Rigolini, and L. Christiaensen, (2012), Natural disasters and growth: Going beyond the averages, World Development 40, 1317-1336.

Nishimura, K.G., T. Nakajima, and K. Kiyota, (2005), Does the natural selection mechanism still work in severe recessions? Examination of the Japanese economy in the 1990s, Journal of Economic Behavior and Organization 58, 53-78.

Noy, I., and T.B. Vu, (2010), The economics of natural disasters in a developing country: The case of vietnam, Journal of Asian Economics 21, 345-354.

Peek, J. and E. Rosengren (1995), The capital crunch: Neither a borrower nor a lender be, Journal of Money, Credit and Banking 27, 625-638.

Peek, J., and E.S. Rosengren, (2005), Unnatural selection: Perverse incentives and the misallocation of credit in Japan, American Economic Review 95, 1144-66.

Sakai, K., I. Uesugi, and T. Watanabe, (2010), Firm age and the evolution of borrowing costs: Evidence from Japanese small firms, Journal of Banking \& Finance 34, 1970-1981.

Schumpeter, J.A. (1939), Business cycles: A theoretical, historical, and statistical analysis of the capitalist process. New York: Mc- Graw-Hill.

Sekine, T., K. Kobayashi, and Y. Saita, (2003), Forbearance lending: The case of Japanese firms, Monetary and Economic Studies 21, 69-92.

Skidmore, M, and H. Toya, (2002), Do natural disasters promote long-run growth?, Economic Inquiry 40, 664-687. 
Table 1 Summary Statistics (Great Tohoku Earthquake)

\begin{tabular}{|c|c|c|c|c|c|c|c|c|c|c|c|c|}
\hline \multirow[b]{2}{*}{ Variable } & & \multicolumn{3}{|c|}{ (1) Whole sample } & \multicolumn{3}{|c|}{ (2) F_DAMAGED=1 } & \multicolumn{3}{|c|}{ (3) F_DAMAGED=0 } & \multicolumn{2}{|c|}{$\begin{array}{c}\text { (4) t-test for coef. } \\
\text { (F_DAMAGED=1) = } \\
(\text { F_DAMAGED }=0)\end{array}$} \\
\hline & & Obs. & Mean & Std. dev. & Obs. & Mean & Std. dev. & Obs. & Mean & Std. dev. & difference & $\mathrm{p}$-value \\
\hline Exit & $\begin{array}{l}\text { Dummy taking a value of one if } \\
\text { the firm is recorded as an exit } \\
\text { firm after the earthquake. }\end{array}$ & 87,470 & 0.00506 & (NA) & 31,447 & 0.00442 & (NA) & 56,023 & 0.00543 & (NA) & (NA) & \\
\hline F_SCORE & TDB's score of the firm. & 87,470 & 43.51218 & 10.56420 & 31,447 & 42.90063 & 10.89666 & 56,023 & 43.85545 & 10.35721 & -0.95483 & 0.000 \\
\hline F_DAMAGED & $\begin{array}{l}\text { Dummy taking a value of one if } \\
\text { the firm is located in one of the } \\
\text { cities or towns identified as } \\
\text { affected by the earthquake in } \\
\text { the Act on Special Financial } \\
\text { Support to Deal with a } \\
\text { Designated Disaster of Extreme } \\
\text { Severity. }\end{array}$ & 87,470 & 0.35952 & 0.47986 & 31,447 & (NA & & 56,023 & (NA & & (NA) & \\
\hline B_HQDAMAGED & $\begin{array}{l}\text { B_HQDAMAGED is a dummy } \\
\text { variable taking a value of one if } \\
\text { the headquarters of a firm's } \\
\text { main bank is located in the } \\
\text { earthquake-affected area. }\end{array}$ & 87,470 & 0.40260 & (NA) & 31,447 & 0.78033 & (NA) & 56,023 & 0.19056 & (NA) & (NA) & \\
\hline B_BRDAMAGED & $\begin{array}{l}\text { B_BRDAMAGED is the ratio } \\
\text { of the number of branches of a } \\
\text { firm's main bank located in the } \\
\text { earthquake-affected area to the } \\
\text { total number of branches of } \\
\text { that bank. }\end{array}$ & 87,470 & 0.34841 & 0.30437 & 31,447 & 0.59584 & 0.26643 & 56,023 & 0.20953 & 0.22615 & 0.38631 & 0.000 \\
\hline F_EMP & $\begin{array}{l}\text { The number of employees of } \\
\text { the firm. }\end{array}$ & 87,470 & 14.20852 & 64.79187 & 31,447 & 15.40036 & 72.09245 & 56,023 & 13.53951 & 60.29821 & 1.86085 & 0.000 \\
\hline F AGE & The age of the firm. & 87,470 & 29.57209 & 17.55012 & 31,447 & 28.81922 & 16.82164 & 56,023 & 29.99470 & 17.93238 & -1.17548 & 0.000 \\
\hline F_NBANK & $\begin{array}{l}\text { The number of banks that the } \\
\text { firm transacts with. }\end{array}$ & 87,470 & 2.06216 & 1.22659 & 31,447 & 2.10456 & 1.32549 & 56,023 & 2.03836 & 1.16675 & 0.06620 & 0.000 \\
\hline B_ROA & $\begin{array}{l}\text { The ratio of operating profit to } \\
\text { total assets of a firm's main } \\
\text { bank. }\end{array}$ & 87,470 & 0.00210 & 0.00122 & 31,447 & 0.00240 & 0.00099 & 56,023 & 0.00193 & 0.00130 & 0.00047 & 0.000 \\
\hline B_CAP & $\begin{array}{l}\text { The equity to assets ratio of a } \\
\text { firm's main bank }\end{array}$ & 87,470 & 0.04605 & 0.01102 & 31,447 & 0.04697 & 0.01103 & 56,023 & 0.04553 & 0.01098 & 0.00144 & 0.000 \\
\hline B_LNASSETS & $\begin{array}{l}\text { The natural logarithm of the } \\
\text { total assets owned by a firm's } \\
\text { main bank }\end{array}$ & 87,470 & 21.10209 & 1.25544 & 31,447 & 21.34001 & 1.42933 & 56,023 & 20.96854 & 1.12449 & 0.37147 & 0.000 \\
\hline
\end{tabular}


Table 2 Summary Statistics (Great Tohoku Earthquake) (at bank level)

\begin{tabular}{|c|c|c|c|c|c|c|c|c|c|c|c|}
\hline \multirow[b]{2}{*}{ Variable } & \multicolumn{3}{|c|}{ Whole Sample } & \multicolumn{3}{|c|}{ B_HQDAMAGED=1 } & \multicolumn{3}{|c|}{ B_HQDAMAGED=0 } & \multicolumn{2}{|c|}{$\begin{array}{c}\text { t-test for coef. } \\
(\text { B_HQDAMAGED=1)) = } \\
(\text { B_HQDAMAGED }=0)\end{array}$} \\
\hline & Obs. & Mean & Std. dev. & Obs. & Mean & Std. dev. & Obs. & Mean & Std. dev. & difference & p-value \\
\hline B_ROA & 120 & 0.002 & 0.00235 & 16 & 0.002 & 0.00117 & 104 & 0.002 & 0.00248 & -0.00042 & 0.50740 \\
\hline B_CAP & 120 & 0.048 & 0.01463 & 16 & 0.044 & 0.01150 & 104 & 0.049 & 0.01498 & -0.00511 & 0.19470 \\
\hline B_LNASSETS & 120 & 21.001 & 1.69323 & 16 & 19.635 & 1.25141 & 104 & 21.211 & 1.65829 & -1.57600 & 0.00040 \\
\hline
\end{tabular}


Table 3 Probit Estimation for Exit Probability

(Great Tohoku Earthquake)

Dependent variable: Dummy for Exit (After Earthquake)

\begin{tabular}{|c|c|c|}
\hline & $\begin{array}{c}(1) \\
\text { B_DAMAGED } \\
= \\
\text { B_HQDAMAGED }\end{array}$ & $\begin{array}{c}(2) \\
\text { B_DAMAGED } \\
= \\
\text { B_BRDAMAGED }\end{array}$ \\
\hline F_SCORE & $\begin{array}{l}-0.0001367 * * * \\
(0.0000225)\end{array}$ & $\begin{array}{l}-0.0001582 \text { *** } \\
(0.0000256)\end{array}$ \\
\hline F_SCORE×F_DAMAGED & $\begin{array}{r}-0.0000633 \\
(0.0000453)\end{array}$ & $\begin{array}{l}-0.0000778 * \\
(0.0000447)\end{array}$ \\
\hline F_SCORE $\times$ B_DAMAGED & $\begin{array}{r}0.000077 * \\
(0.0000464)\end{array}$ & $\begin{array}{r}0.0001677 * * \\
(0.0000762)\end{array}$ \\
\hline F_DAMAGED & $\begin{array}{r}0.0027436 \\
(0.0023854)\end{array}$ & $\begin{array}{r}0.0036726 * \\
(0.0024978)\end{array}$ \\
\hline B_DAMAGED ${ }^{\dagger}$ & $\begin{array}{l}-0.0039936 * * \\
(0.0018679)\end{array}$ & $\begin{array}{l}-0.0089731 * * * \\
(0.0033377)\end{array}$ \\
\hline F_EMP & $\begin{array}{r}-0.0000101 * \\
(0.00000553)\end{array}$ & $\begin{array}{r}-0.0000102 * \\
(0.00000551)\end{array}$ \\
\hline F_AGE & $\begin{array}{r}0.0000126 \\
(0.0000117)\end{array}$ & $\begin{array}{r}0.0000126 \\
(0.0000117)\end{array}$ \\
\hline F_NBANK & $\begin{array}{r}0.0014272 \text { *** } \\
(0.0001461)\end{array}$ & $\begin{array}{r}0.0014231 \\
(0.0001459)\end{array}$ \\
\hline B_ROA & $\begin{array}{r}-0.2495632 \\
(0.1627927)\end{array}$ & $\begin{array}{r}-0.2153491 \\
(0.1649626)\end{array}$ \\
\hline B_CAP & $\begin{array}{l}-0.0413277 * * \\
(0.0191047)\end{array}$ & $\begin{array}{l}-0.0412683 * * \\
(0.0190393)\end{array}$ \\
\hline B_LNASSETS & $\begin{array}{r}-0.0002491 \\
(0.000176)\end{array}$ & $\begin{array}{r}-0.0002588 \\
(0.0001756)\end{array}$ \\
\hline Obs & 87470 & 87470 \\
\hline LR chi2 & 216 & 219.35 \\
\hline p-value & 0 & 0 \\
\hline Pseudo R-squared & -2675.3462 & -2673.6676 \\
\hline Log likelihood & 0.0388 & 0.0394 \\
\hline
\end{tabular}

Notes: Heteroskedasticity-robust standard errors are reported in parentheses. $* * *, * *$, and * indicate significance at the 1,5 , and $10 \%$ level, respectively. The significance level of the sum of the coefficients on B_DAMAGED and $F \_D A M A G E D \times B \_D A M A G E D$ is based on the F-values under the null hypotheses that the sum is zero.

† The $B \_D A M A G E D$ variable is either $B \_H Q D A M A G E D$ or $B \_B R D A M A G E D$ as indicated in the column heading. 
Figure 1 Bank damage and exit probability

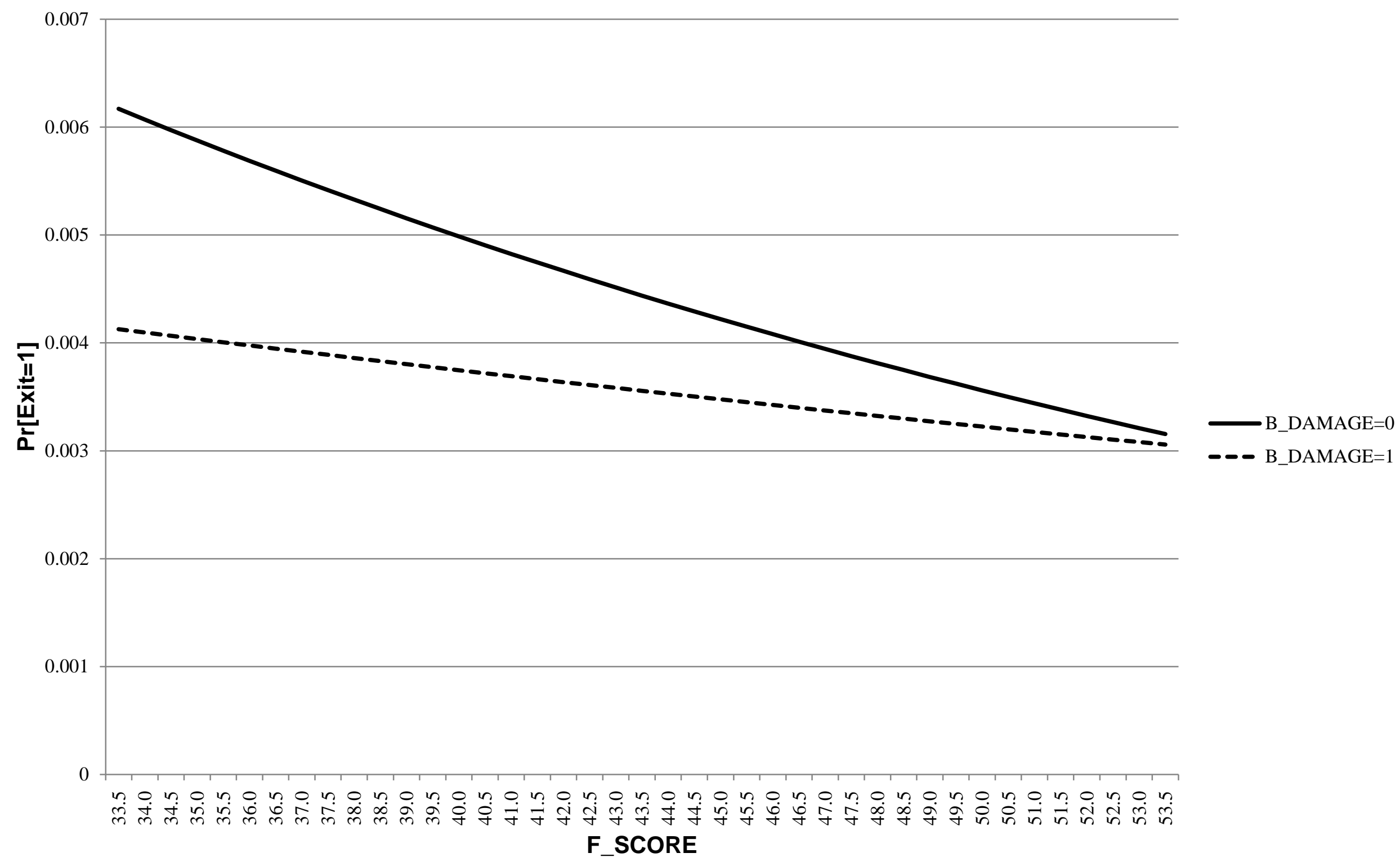


Table 4 Summary Statistics (Great Hanshin-Awaji Earthquake)

(1) Whole sample
(2) F_DAMAGED=1

\begin{abstract}
Variable
\end{abstract}
Exit

F_ROA

F_DAMAGED

B_HQDAMAGED

B_BRDAMAGED

F_EMP

F AGE

F_NBANK

F_CASH

F_LEV

B_ROA

B CAP

B LNASSETS

0.01495 (NA)

Obs.

Mean

Mean

0.38404

2,429

$\begin{array}{llll}13,509 & 0 & 0.38404 & 2,429\end{array}$

$13,509 \quad 0$ (NA)

(N)

(NA)

$\begin{array}{rrrr}13,509 & 0 & 0.18875 & 2,429\end{array}$

$\begin{array}{lrrrrr}13509 & 135.0 & 922.11050 & 2,429 & 110.43100 & 615.70710\end{array}$

13509

$44.5 \quad 15.50305$

13509

$\begin{array}{ll}4.0 & 2.31158 \\ 0.2 & 0.13303\end{array}$

$2,429 \quad 0.17269$

$0.0 \quad 0.00955$

\begin{tabular}{rr}
2,429 & 0.03817 \\
2,429 & 23.03319 \\
\hline
\end{tabular}

$23.2 \quad 1.89149$

Std. dev
(NA)
0.15374

Std. dev.

$\begin{array}{ll}\text { (NA) } & 11,080 \\ \text { (NA) } & 11,080\end{array}$

(3) F_DAMAGED $=0$

$0.29360 \quad 11,080$

$2,429 \quad 44.08934 \quad 15.26895$

11,080

$\begin{array}{rrrr}2,429 & 44.08934 & 15.26895 & 11,080 \\ 2,429 & 3.88720 & 2.27434 & 11,080\end{array}$

140.33390

$11,080 \quad 44.63213$

$11,080 \quad 4.07464$

$\begin{array}{lrrrrrr}44.8 & 4294.946 & 2,429 & 7.44559 & 122.612 & 11,080 & 53.02928\end{array}$

\begin{tabular}{rrrrr}
2,429 & 7.44559 & 122.612 & 11,080 & 53.02928 \\
\hline & 0.00183 & 0.00121 & 11,080 & 0.00181
\end{tabular}

$\begin{array}{lllll}2,429 & 0.03817 & 0.00886 & 11,080 & 0.03833\end{array}$

0.00886

$\begin{array}{rr}11,080 & 0.03833 \\ 11,080 & 23.25917\end{array}$

.9832

$\begin{array}{rrr}11,080 & 0.03833 & 0.00969 \\ 11,080 & 23.25917 & 1.86842\end{array}$

(NA)

$\begin{array}{llr}0 & 0.15092 & -0.00742\end{array}$

(NA)

(NA)

$(\mathrm{NA})$

(4) t-test for

$($ F_DAMAGED=1) =

(F_DAMAGED $=0$ )

liquid assets to total assets, F_LEV is the ratio of firms' liabilities to equity. 
Table 5 Probit Estimation for Exit Probability (Great Hanshin-Awaji Earthquake)

\begin{tabular}{|c|c|c|}
\hline \multicolumn{3}{|c|}{ Dependent variable: Dummy for Exit (After Earthquake) } \\
\hline & $\begin{array}{c}(1) \\
\text { B_DAMAGED } \\
= \\
\text { B_HQDAMAGED }\end{array}$ & $\begin{array}{c}\text { (2) } \\
\text { B_DAMAGED } \\
= \\
\text { B_BRDAMAGED }\end{array}$ \\
\hline F_ROA & $\begin{array}{l}-0.0064038 * * * \\
(0.0028147)\end{array}$ & $\begin{array}{l}-0.0054724 * * \\
(0.0028718)\end{array}$ \\
\hline F_ROA × F_DAMAGED & $\begin{array}{r}-0.0017012 \\
(0.0079827)\end{array}$ & $\begin{array}{r}0.0007416 \\
(0.0050525)\end{array}$ \\
\hline F_ROA $\times$ B_DAMAGED & $\begin{array}{r}-0.0007701 \\
(0.0085363)\end{array}$ & $\begin{array}{r}-0.0096628 \\
(0.0117989)\end{array}$ \\
\hline F_DAMAGED & $\begin{array}{r}-0.0009929 \\
(0.0006224)\end{array}$ & $\begin{array}{r}-0.0006661 \\
(0.0006431)\end{array}$ \\
\hline B_DAMAGED ${ }^{\dagger}$ & $\begin{array}{r}-0.0005882 \\
(0.0007893)\end{array}$ & $\begin{array}{l}-0.0027994 * \\
(0.0016773)\end{array}$ \\
\hline F_EMP & $\begin{array}{l}-0.0000179 \text { *** } \\
(0.00000335)\end{array}$ & $\begin{array}{l}-0.0000177^{* * *} \\
(0.00000332)\end{array}$ \\
\hline F_AGE & $\begin{array}{l}-0.0000812 * * * \\
(0.0000344)\end{array}$ & $\begin{array}{l}-0.0000803 * * * \\
(0.0000341)\end{array}$ \\
\hline F_NBANK & $\begin{array}{l}0.0006933 \text { *** } \\
(0.0002024)\end{array}$ & $\begin{array}{r}0.0006816 * * * \\
(0.0001997)\end{array}$ \\
\hline F_CASH & $\begin{array}{l}-0.0149101 \text { *** } \\
(0.0046903)\end{array}$ & $\begin{array}{l}-0.0148128 \text { *** } \\
(0.0046629)\end{array}$ \\
\hline F_LEV & $\begin{array}{r}6.84 \mathrm{E}-09 \\
(0.0000000863)\end{array}$ & $\begin{array}{r}\text { 6.79E-09 } \\
(0.0000000862)\end{array}$ \\
\hline B_ROA & $\begin{array}{r}-0.3326426 \\
(0.2614721)\end{array}$ & $\begin{array}{r}-0.2937703 \\
(0.2542216)\end{array}$ \\
\hline B_CAP & $\begin{array}{r}0.0300266 \\
(0.0369074)\end{array}$ & $\begin{array}{r}0.0261641 \\
(0.034133)\end{array}$ \\
\hline B_LNASSETS & $\begin{array}{l}-0.0003022 * \\
(0.0001838)\end{array}$ & $\begin{array}{l}-0.0003382 * * \\
(0.0001863)\end{array}$ \\
\hline Obs & 13509 & 13509 \\
\hline LR chi2 & 872.31 & 875.99 \\
\hline p-value & 0 & 0 \\
\hline Pseudo R-squared & 0.4156 & -611.46171 \\
\hline Log likelihood & -613.29951 & 0.4174 \\
\hline Industry dummies & yes & yes \\
\hline
\end{tabular}

Notes: Heteroskedasticity-robust standard errors are reported in parentheses. $* * *$, **, and * indicate significance at the 1, 5, and 10\% level, respectively. The significance level of the sum of the coefficients on B_DAMAGED and F_DAMAGED $\times$ B_DAMAGED is based on the F-values under the null hypotheses that the sum is zero.

† The B_DAMAGED variable is either B_HQDAMAGED or B_BRDAMAGED as indicated in the column heading. 